\title{
Rain Barrel Owners: Meeting the Programming Needs of This Unique Extension Audience ${ }^{1}$
}

\author{
Emily Ott, Paul Monaghan, Wendy Wilber, Lynn Barber, and Karissa Raymond ${ }^{2}$
}

\section{Introduction}

As the population of Florida continues to grow past 20 million, promoting water conservation behaviors among the public becomes increasingly important, putting a greater demand on the time and resources of Extension faculty. Residential landscapes with in-ground irrigation can comprise between $46 \%$ and $75 \%$ of total household water use (Dukes, Miller, \& Haley, 2005). This provides many opportunities for Extension to increase public conservation. There are many technological, educational, and behavioral interventions for outdoor water savings, including smart sensor controllers, prompts and reminders, turfgrass replacement, and training in hands-on management of irrigation timers. Each of these is estimated to save between 11,000-155,000 gallons annually for a typical lawn (Boyer and Dukes, 2015).

Rain barrels (typically 55-90 gallon containers that collect rainwater from rooftops) are another technology endorsed by Extension to conserve water. Programs in rain barrel construction, decorating, and giveaways are popular Extension events in Florida and around the country (Backacs, Haberland, \& Mangiafico, 2013). Research has shown that rain barrel use can be an indicator of how households view water conservation and may predict how they adopt other conservation practices.
This EDIS document will provide insight into the behavior and attitudes of rain barrel owners, an important segment of the Extension audience. It will also offer best practices and suggestions to help agents make rain barrels more effective and increase the impact and scope of Extension water conservation programs in general. The households that install rain barrels are often the "innovators" and first adopters of many of the water conservation behaviors promoted by agents around the state. As a unique target audience, Extension would benefit by partnering with these early adopter households to disseminate information regarding water conservation technologies to their neighbors. The first step is to help rain barrel adopters successfully utilize this technology and troubleshoot for problems.

\section{Benefits of Rain Barrels}

Rain barrels help preserve water quality by slowing the flow of stormwater runoff that may carry pollutants and nutrients downstream during strong rain events. Rain barrels can also provide good quality water for reuse on plants or lawns, which saves municipal or well water. Capturing rainwater can conserve our groundwater resources which are currently being pumped for landscape irrigation at unsustainable levels. Also, rainwater provided by rain barrels has a slightly acidic $\mathrm{pH}$ and assists nutrient availability for lawns and gardens (Forsyth County Extension Services, 2015; Kloss, 2008; Minnesota Pollution Control Agency,

1. This document is AEC634, one of a series of the Department of Agricultural Education and Communication, UF/IFAS Extension. Original publication date March 2018. Visit the EDIS website at http://edis.ifas.ufl.edu.

2. Emily Ott, research assistant; Paul Monaghan, associate professor; Wendy Wilber, Extension agent III; Lynn Barber, Extension agent II; and Karissa Raymond, graduate assistant; Department of Agricultural Education and Communication; UF/IFAS Extension, Gainesville, FL 32611. 
2015; Rutgers University, 2014; Texas Water Development Board, 2005).

Rain barrel programs not only provide the public with applicable water conservation skills, but can introduce the public to Extension services at large (Kloss, 2008; Rutgers University Water Resources Program, 2014). Many state and local agencies support rain barrel programs and provide informative materials to the public, such as the following guide produced by the Southwest Florida Water Management District http://www.swfwmd.state.fl.us/ publications/files/rain_barrels_guide.pdf.

\section{Rain Barrel Owners: Engaging a Unique Extension Audience}

Rain barrels save comparatively less water than other technological approaches. They rarely hold enough to meet the water needs of turfgrass landscapes, especially in the event of a drought. Despite this, a recent study found that even when respondents had difficulties with their rain barrel(s), they still had a positive opinion of them (Ott, Monaghan, Israel, Gouldthorpe, \& Wilber, 2015). So what makes this audience so unique?

A survey of landscaping behaviors and attitudes of Extension clientele was conducted using the email address list compiled by a county environmental horticulture agent for dissemination of her electronic newsletter (Ott et al., 2015). Responses to the electronic survey revealed rain barrel owners to be a unique group of residents. Of the 535 respondents, 189 (35\%) had rain barrels. This high percentage was because many of their emails were placed on the newsletter list after they had attended an Extension rain barrel program. Nevertheless, these rain barrel owners reported significantly different behaviors from those households that did not have a rain barrel. Households with a rain barrel were found to:

- Be less likely to have an in-ground irrigation system

- Water their yards less often, even with in-ground irrigation

- Be more likely to do their own yardwork

- Apply fertilizer to their lawns less frequently

- Be more likely to conserve water indoors

These behaviors may indicate that rain barrel owners have a "water saving ethic," are more aware of the water needs of their yards, and may be more likely to conserve water in other ways besides rain barrels. These individuals perceive water resources to be valuable and, thus, manage their landscapes in more effective ways (Ott et al., 2015). Based on these results, we suggest rain barrel owners may be a unique "audience segment" for Extension-people who understand the water and nutrient needs of their landscape and actively take steps to protect the environment.

As an "audience segment," these households are considered innovators or early adopters of water conservation technology (Monaghan et al., 2014). Extension may look at them as potential opinion leaders in their communities because the visibility of rain barrels in their yards may influence other neighbors to adopt the technology as well (McKenzieMohr, 2011; Rogers, 2003). Therefore, this "audience segment" can help Extension promote the adoption of rain barrel use, and other water conservation strategies, by shifting the social norms in the neighborhood (McKenzieMohr, 2011; Monaghan et al., 2014; Ott et al., 2015; Stern, 2000). Rain barrel presentations and workshops are an opportunity for Extension agents to promote or establish links to other environmental Extension programs, such as Florida-Friendly Landscaping ${ }^{\mathrm{TM}}$ and Sustainable Floridians (Florida-Friendly Landscaping ${ }^{\mathrm{TM}}$ Program, 2009; UF/IFAS Extension, 2008).

\section{Opportunities for Extension to Facilitate Adoption of Rain Barrels}

Another strategy to increase the impact of rain barrel programs is for Extension agents to help lower the barriers faced in satisfactorily adopting the technology (Warner et al., 2015). Barriers to rain barrel ownership, installation, and utilization were identified from open-ended responses to questions in the survey. Concerns and issues presented by respondents indicated opportunities for Extension to develop and deliver solutions for rain barrel owning clientele. These solutions should focus on the following:

I. Rain barrel installation

II. Designing the system based on clients' needs

III. Improving clients' experience via increased rain barrel productivity

IV. Improving the safety and longevity of rain barrel systems

Below, we discuss each of these issues, provide examples of client survey responses, and explain troubleshooting and solutions that Extension agents, Master Gardeners, and 
water educators can provide to help clients make better use of their rain barrels.

\section{Rain Barrel Installation}

Having a good water catchment design and initial plan is important for rain barrels to be more effective (Texas Water Development Board, 2005). Teaching clients to install their rain barrel system in a safe and convenient location will increase their full adoption of the technology (Backacs, Haberland, \& Mangiafico, 2013). This was underscored by the survey respondents who owned rain barrels but had either not installed them or did not install them properly.

- "While I have one, I haven't actually set it up."

- "They look great; can’t wait to set them up."

- "I would be satisfied if I had it hooked up properly - time constraints."

- "Water a few plants in the backyard... really need it in the FRONT yard where more plants are that need water, but no time to do it, too much effort required."

Most rain barrels are installed in the backyard. If a resident lives in a deed-restricted community, they should review the documents to determine whether rain barrels are allowed. If not, one possible solution is for the homeowner to meet with the architectural or landscape review committee to present their case for installing a rain barrel.

\section{ELEVATING A RAIN BARREL SAFELY}

Installing rain barrels above the ground is important for two reasons:

- In order to fit a bucket or watering can underneath the outflow or spigot at the bottom of the barrel (Tennessee Yards \& Neighborhoods, n.d.)

- In order to increase the pressure and speed at which the water will empty from the outflow or spigot (College of Charleston Office of Sustainability, n.d.; Stormwater Coalition of Albany County, 2010; Tennessee Yards \& Neighborhoods, n.d.)

Caution should be exercised when installing a barrel on a platform. Since water weighs around 8.34 pounds per gallon, a full 55-gallon rain barrel can weigh over $450 \mathrm{lbs!}$

A strong, level, and secure base for a rain barrel is essential to keep a barrel from tipping, sliding, falling, and causing damage to property or harm to people or animals (City of Portland Environmental Services, 2011; Stormwater Coalition of Albany County, 2010; Tennessee Yards \& Neighborhoods, n.d).

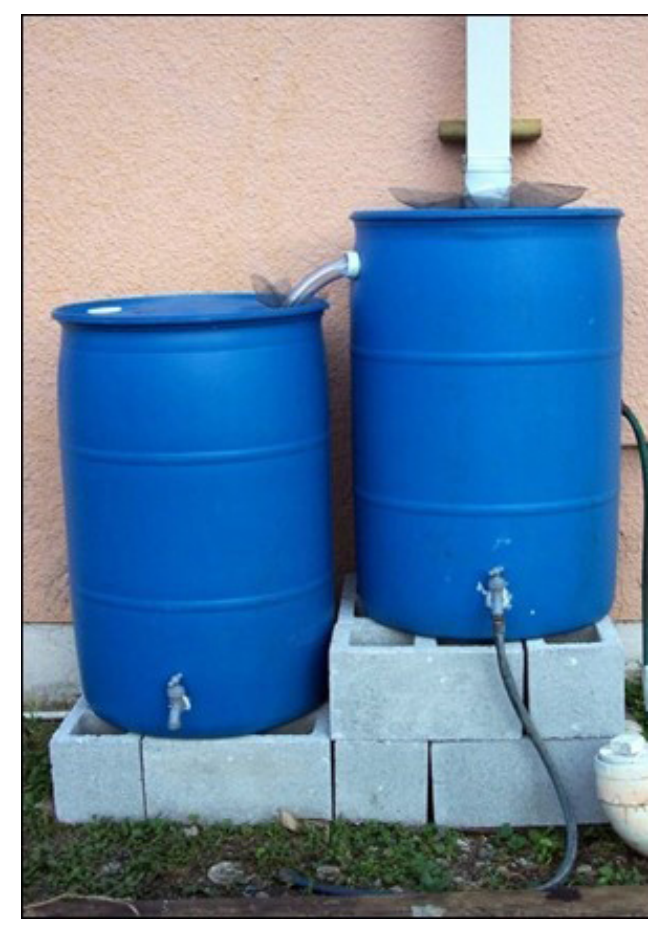

Figure 1. Stably elevated rain barrel. Credits: UF/IFAS

\section{INSTALLATION WITH GUTTER SYSTEM}

For clients who have existing gutters, installing their rain barrel at one of the downspouts is a good option. This installation is a relatively simple project as long as clients purchase or have the appropriate tools and additional necessary hardware (Angima, 2014; College of Charleston Office of Sustainability, n.d). Extension educators can utilize installation videos specific to the type of rain barrel they sell or give away. A video of an actual installation may help people who have acquired a rain barrel take the first step towards full adoption:

https://youtu.be/PDDHjr36aG0

https://www.youtube.com/watch?v=yaKkEz0OcQI

\section{INSTALLATION WITHOUT GUTTERS}

Other respondents indicated they did not have gutters on their house, which prevented them from installing or efficiently using their rain barrels. Extension should educate homeowners that a lack of gutters does not prohibit installing a rain barrel. Placing rain barrels at a "V" along the roofline will also enable water capture (Angima, 2014).

- "It is not the rain barrel's fault! We do not have gutters and so the rain does not efficiently enter the barrel."

- "I have them, but have not yet integrated them into my gutter and watering solution. Actually, I don't yet have a 
gutter and watering system that will work with them. I am hoping to correct that soon."

- "The rain barrel highlighted problems that I have with my roof gutters. It would be nice to see videos... that show how to reconfigure the gutters."

\section{ACCOUNTING FOR OVERFLOW}

An overflow outlet is an important part of a rain barrel's design. This hole near the top of the barrel will allow water to escape when the barrel has reached capacity and rain is continuing to fill it (College of Charleston Office of Sustainability, n.d.; Rutgers University Water Resources Program, 2014). Lack of an overflow outlet can lead to overflow and erosion, compromising the stability of the barrel. A hose should be attached to the overflow outlet so that the excess water can be directed away from a building's foundation and towards plants that could use it (City of Portland Environmental Services, 2011). An overflow outlet can also be piped to another barrel in a linked-barrel design, which increases the amount of water the system is able to capture. However, even with a linked-barrel design, an overflow outlet is still needed (Angima, 2014; Tennessee Yards \& Neighborhoods, n.d.). The size of the overflow should be similar to the size of the in-flow. If not, the water will overflow out of the top of the barrel, causing erosion.

\section{Designing the System Based on Clients' Needs}

Prior to helping clients design rainwater harvesting systems that will meet their needs, Extension must first learn how the clients want to use their captured rain water and what concerns they may have (Warner et al., 2015). Then, after assessing how much rainwater is likely to be captured by the client's roof, Extension can explain the limitations of water capture capacity to the clients, helping them understand which parts of their yards can be supplemented by rain barrel water. In this way, Extension can help clients develop more realistic expectations of their rain barrels and improve clients' sustained use of rainwater harvesting systems.

\section{DETERMINING CLIENTS' DESIRED USE FOR CAPTURED RAINWATER}

Determining how the water captured by their rain barrel(s) will be used is an important step that Extension can help clients make. Rainwater is good for plants because it contains no chlorine or fluoride, is free of other salts and minerals used in water treatment, and tends to be highly oxygenated (Hartup \& Ellis, 2007). One barrel will likely meet their need for supplemental water for a few non-edible plants or a small area of their yard (Rutgers University Water Resources Program, 2014).

If a client wants to irrigate a large portion of their yard, they will need more water than one 55-gallon rain barrel can consistently provide. One 55-gallon rain barrel can provide 1" of water to an 88 square foot planted area (Tennessee Yards \& Neighborhoods, n.d.). Estimating water demand is an important place to start for those clients looking for an irrigation replacement.

Extension agents should direct clients to EDIS resources on watering Florida lawns that can help them water their yards appropriately. Such documents include:

- Watering Your Florida Lawn (ENH9) available from https://edis.ifas.ufl.edu/lh025,

- Summary of IFAS Turf and Landscape Irrigation Recommendations (AE436) available from http://edis.ifas.ufl. edu/ae436, which provides a table of additional resources.

Once clients know how much water they will need to capture to irrigate their yard, they can make a betterinformed decision about a rain barrel system design. To meet the water needs of a large section of a yard, they may want to invest in a larger device, such as a cistern or tote, to capture rain water (Angima, 2014; City of Portland Environmental Services, 2011; Texas Water Development Board, 2005). Other options include installing multiple barrels, either at different locations or linked together at one convenient location, or leaving room for increasing the number of barrels in their rain barrel system (Texas Water Development Board, 2005).

\section{ADDRESSING CLIENTS' CONCERNS}

One of the most common concerns raised by these respondents was that the barrels were not large enough to meet the water needs of their yard and/or plants. Other respondents who indicated they were satisfied seemed to be aware of the rain barrel's limited capacity. These people knew the water in the barrel would irrigate only some of their plants or yard. Most participants who raised this issue said things like:

- "For the area it waters it is sufficient."

- "No. It does not have the capacity to catch enough water. It runs out way too fast."

- "Yes. Although now I wish it came in a larger size."

Agents can address the problem of limited capacity of rain barrels by helping clients estimate their landscape watering 
needs, the rate at which one rain barrel will fill based on the roof area that will drain into the barrel, and the volume of water they will likely capture during an average rain event (Angima, 2014; College of Charleston Office of Sustainability, n.d.). With this information, clients can make a better-informed choice about how many barrels of water they will likely need to supplement specific areas of their yards and the most appropriate places to install them.

\section{ASSESSING THE WATER CAPTURE CAPACITY OF ROOFTOPS}

As a rule of thumb, one half-gallon of rainwater per square foot of roof area will run off a roof during a one-inch rainfall (Southwest Florida Water Management District, n.d.). This means that a 2,000 square foot roof can collect more than 1,000 gallons of water in one one-inch rainfall, or more than 18 rain barrels worth of water (Southwest Florida Water Management District, n.d.). Information on sizing a roof catchment area can be found at https://catalog. extension.oregonstate.edu/files/project/pdf/em9101.pdf

Despite the limitations of the technology, the survey indicated rain barrels can function quite adequately as a source of supplemental water for household landscapes. Responding to the open-ended question, "Are you satisfied with your rain barrel? Why or why not?," most survey respondents indicated they were. People who responded said things like:

- "Yes. It's nice to collect that extra bit for the plants."

- "Yes! So functional... it holds me over (with watering plants) until the next rain."

- "Yes. Once the rain barrels are installed they're a low maintenance, easy way to collect water."

\section{Strategies for Improving Rain Barrel Productivity}

Providing information to clients that will improve their experiences using rain barrels is important when promoting water conservation behaviors. Because many clients express concern regarding the limited utility of rain barrels due to limited water capacity, educating clients on how to improve the productivity of their rainwater harvesting system is essential for improving rates of adoption (Backacs, Haberland, \& Mangiafico, 2013). Therefore, once a client's needs and desired uses for rain barrel catchment have been identified, Extension should educate clients about specific solutions that address the barriers they are facing and improve the efficiency of their system (Warner et al., 2015).
INCREASING WATER CAPACITY VIA MULTIPLE AND LINKED BARRELS

Some respondents believed the issue of limited water capacity would be solved by installing multiple rain barrels. When describing their satisfaction with their rain barrel, these participants made statement such as:

- "It's ok. Could probably use another, as it doesn't seem to hold enough water during a dry spell."

- "Yes, but I want to put one in the back yard, too. I am satisfied because I can water plants in front yard with it."

- "In process of adding additional barrels- one barrel does not have large enough capacity."

Of these respondents who wanted additional barrels, many expressed interest in linking barrels together so rain would overflow into a subsequent barrel rather than losing the water out of the container (Figure 2):

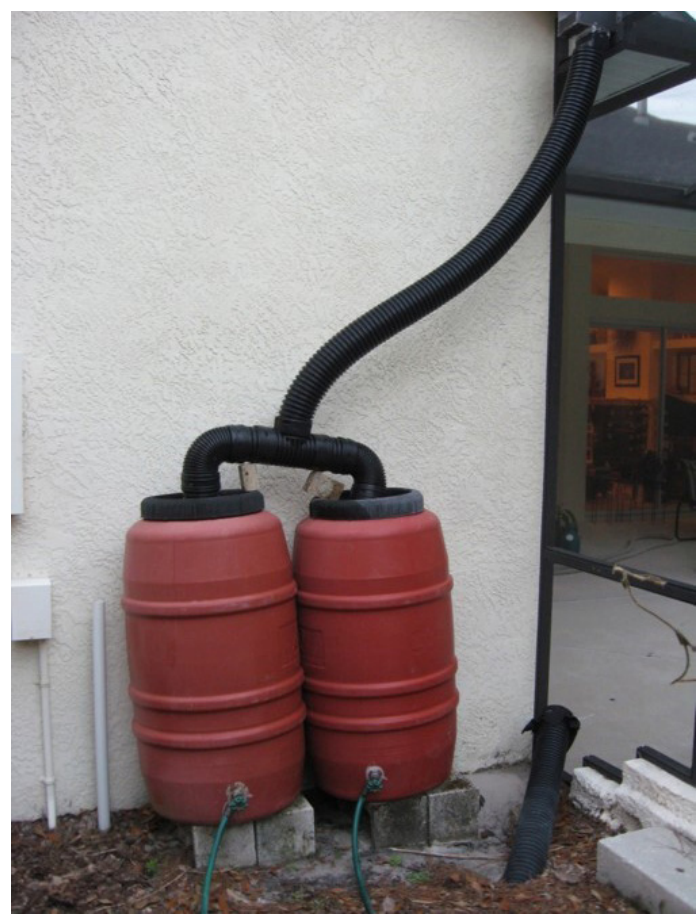

Figure 2. Good linked barrel design, but not level.

Credits: Lynn Barber, UF/IFAS

- "Yes, but I underestimated the amount of water I needed for the garden and think I'll buy at least one more. I like the design for connecting barrels together."

- "No-this year I could have used additional overflow barrels, which I will work on for the coming year."

- “They are ok, but I didn't realize they would fill up so quickly. I've been keeping hoses attached to them to direct the overflow, but that means they get drained when it rains so the plants are getting the extra water only when it rains." 


\section{TROUBLESHOOTING LOW PRESSURE}

If a client wants to use rain barrel water far away from the rain barrel, they will likely need a pump to pressurize the barrel or draw the water out with more force than gravity alone (City of Portland Environmental Services, 2011). In the event that a hose has been attached to a spigot at the bottom of a barrel, water will flow out of the hose only when it is held below the rain barrel water level. One of the most common issues with rain barrels mentioned by the survey respondents was that the barrels had low pressure:

- "Wish there was a way to pressurize it so as to use a hose and not to have to carry water in buckets."

- "Yes, but slow gravity fed hose is aggravating."

- "Yes. However the main issue is raising the barrel high enough to create sufficient pressure to use a hose rather than water can to distribute water."

Using two concrete blocks as the platform for one rain barrel is a solution. Extension programming focused on solving this prevalent issue can help clients more easily and efficiently utilize the rain barrels they received and/or purchased. Survey results indicated that some participants could benefit from Extension guidance to avoid installing their barrels too low or by installing pumps to help pressurize the water:

- "It would... be nice get ideas to safely elevate the rain barrel so that it is 2 or 3 feet above ground level."

- "Yes. But it is lower than my garden so I can't drip irrigate, I have to bucket the water up to the garden which is time consuming"

- "I love it, I need to place it on cement blocks so it is easier to fill buckets."

- "Not enough water pressure. Cannot set it high enough to get adequate flow. Bought a submersible pump to make them more usable."

- "Somewhat. It would be nice to have a solar pump of some sort to move the water further."

\section{Improving the Safety and Longevity of Rain Barrel Systems}

Once clients have installed rain barrels at their homes, the role of Extension is not complete. Clients must be educated on maintenance practices that will ensure the functionality of their rain barrels over time. In addition, it is also essential for Extension to explain the potential safety risks that can result from leaving a rain barrel unmaintained.
Extension should work with clients to improve their self-efficacy and commitment to properly maintaining their rain barrel systems (Warner \& Monaghan, 2013).

\section{MAINTENANCE}

Cleaning the inside of the barrel periodically is an important step in keeping a rain barrel working properly. If a barrel has been constructed from a recycled food barrel, it should be cleaned with dish soap, water, and a scrub brush to remove food residue or particles. If the barrel is NOT a food grade barrel, it likely contained some type of chemical and should NOT be used to harvest rain water. After a barrel has been installed, it should be checked periodically for sediment buildup, debris, and algae growth (Angima, 2014; College of Charleston Office of Sustainability, n.d.). A barrel should be emptied and disconnected from the downspout for cleaning. Before and after the rainy season would be appropriate times to clean gutters and rain barrels of debris; otherwise, this can be done as needed.

\section{POSSIBLE CONTAMINANTS IN RAIN BARREL WATER}

Rain barrel water is not potable, meaning it should not be used for human consumption. Roofing materials (tar and gravel, asbestos shingle, asphalt shingle, treated wood shingles or shakes, and copper roofs) can contaminate rain barrel water with chemicals (Backacs, Haberland, Yergeau, et al., 2013; Mendez, Afshar, Kinney, Barrett, \& Kirisits, 2010; Texas Water Development Board, 2005). If a chemical cleaner or soap is used to clean the roof or siding, rain barrels should be disconnected to prevent entry into the barrel. Biological contaminants, such as bird droppings, can contain harmful bacteria that can contaminate the rain barrel water. In addition to potential chemical and bacterial pollutants, other sediments such as leaves, pine needles, twigs, and pollen can clog the barrel's components.

\section{KEEPING LEAVES AND DEBRIS OUT OF RAIN BARRELS}

By following up with rain barrel clients, Extension can share information about commercially available products to keep rain barrel water clean and free of sediments and debris. There are several innovations that can help clients achieve this goal. Starting with the gutters, there are many designs and brands of materials designed to screen and protect gutters from leaves. Extension programming could include tips on using gutter guards and screens to help clients more easily and safely keep leaves and other sediments from entering and/or clogging their gutters and, subsequently, their rain barrels. Other rain barrel accessories like "leaf eaters" or other filters can be installed closer to the entrance 
of the barrel, which are also designed to prevent leaves and debris from entering the rain barrel inflow. These innovations can help to keep the barrel spigots clear and working. Participants discussed issues they had with maintaining clean gutters:

- "Does not take much effort but keeping leaves out of the rain gutters is a pain."

- "Hoses get clogged up with debris, otherwise they are helpful."

- "Yes. I do have to do some maintenance (removing leaves and such) every once and awhile, but I don't mind."

\section{FIRST FLUSH DIVERTER}

Another way to lower contamination and sediment buildup in a barrel is a "first-flush diverter" or "roof washer" (Angima, 2014). This is a device that captures the first water that falls on the roof, which tends to be the dirtiest. Typically, the first 5-10 gallons per 1,000 sq ft of roof should be prevented from entering the barrel (KinkadeLevario, 2007). First flush diverters can be purchased from numerous vendors online, or built with materials from hardware stores. More information on first flush diverters is available at http://www.ctahr.hawaii.edu/hawaiirain/ downloads/5_flush.pdf.

\section{PAINTING RAIN BARRELS}

Painting the barrel can be a fun way of making a barrel more aesthetically pleasing and part of the home landscape (Figure 3). Knowing how residents value the norms and approval of their neighbors, a painted and attractive rain barrel can be an outward sign of commitment to water conservation (McKenzie-Mohr, 2011; Rutgers University Water Resources Program, 2014). Painting the barrel also helps prevent sunlight from entering and may reduce algae growth in barrels that are made of white or clear plastic materials. By preventing the growth of algae, clients can improve the cleanliness and safety of their captured water, reduce clogging of the barrel components, and extend the time between barrel cleanings.

\section{MOSQUITO CONTROL}

Keeping bugs, especially mosquitoes, out of rain barrels is important for the quality of the water inside the barrel and neighborhood safety. Installing screens, mesh, or even nylon stocking material over the inflow and outflow areas of the barrels will help keep mosquitoes and other pests out (City of Portland Environmental Services, 2011). Barrels should be constructed so that screens can be easily replaced if they are damaged. Clients should periodically inspect their screens for holes and their barrels for mosquito larvae.

Another means of protection against mosquitoes in rain barrels is a mosquito dunk (or mosquito tab) that uses bacteria to kill mosquito larvae and control the population. Apply according to the instructions on the package. More information on controlling mosquitoes in rain barrels and yards can be found at http://gardeningsolutions.ifas.ufl.edu/ giam/problems/diseases_and_pests/water_mosquitoes.html
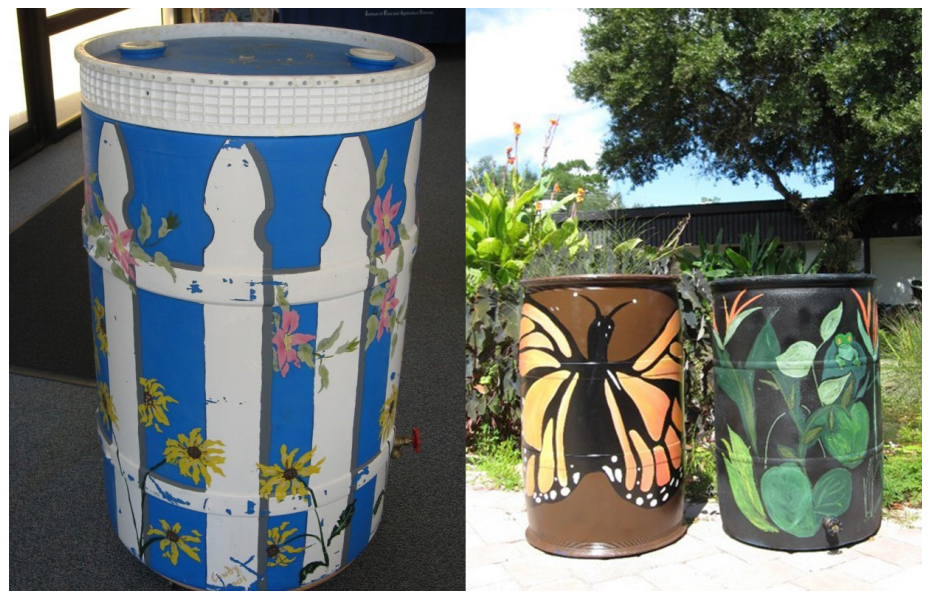

Figure 3. Painted rain barrels. Credits: Lynn Barber, UF/IFAS

\section{COLD WEATHER}

In most places in Florida, a rain barrel will typically not need special attention or maintenance in the winter. If a hard freeze is expected, however, barrels should be emptied of all water to prevent freezing, which could crack the barrel and ruin the barrel components. Special attention should be given to the rain barrel spigot and outflow connection. These components can be dried or even wrapped in a rag or old cloth to prevent water potentially trapped inside from freezing and damaging those parts of the rain barrel. Utilization of brass spigots versus plastic, which disintegrate in extended heat/sun exposure, is a longer-lasting option.

\section{Conclusion}

Rain barrels can be a great introduction to water conservation behaviors and the other educational programs Extension has to offer. Extension programs about rain barrels can provide basic and advanced information depending on a client's needs. Master Gardeners can play a key role in helping to troubleshoot rain barrel issues for clients' satisfaction. The technology is hands-on and appealing to conservation values. Most importantly, rain barrels can be highly visible, demonstrating to others in their neighborhood that saving water is easy and that Extension can help them do it. 
The responses to our survey of rain barrel owners highlighted some key issues that even enthusiastic early adopters may have with this technology, thereby identifying important areas for Extension to address via future educational and outreach efforts:

- Rain barrel installation

- Designing the system based on clients' needs

- Improving clients' experience via increased rain barrel productivity

- Improving the safety and longevity of rain barrel systems

\section{References}

Angima, S. (2014). Rainwater harvesting for use in the garden. https://catalog.extension.oregonstate.edu/files/ project/pdf/em9101.pdf

Backacs, M. E., Haberland, M., Mangiafico, S., Winquist, A., Obropta, C. C., Boyajian, A., \& Mellor, S. (2013). Rain barrels: A catalyst for change? Journal of Extension. 51(3). Retrieved from http://www.joe.org/joe/2013june/rb6.php

Backacs, M., Haberland, M., \& Yergeau, S. (2013). Rain barrels part IV: Testing and applying harvested water to irrigate a vegetable garden. Retrieved from https://njaes. rutgers.edu/pubs/fs1218/

Boyer, M., \& Dukes, M.D. (2015). Estimated water savings potential of Florida-Friendly Landscaping activities. AE515. Gainesville: University of Florida Institute of Food and Agricultural Sciences. http://edis.ifas.ufl.edu/ae515.

College of Charleston Office of Sustainability. (n.d.). So you're installing a rain barrel system! Helpful tips from the office of sustainability [Fact sheet]. Retrieved from http:// sustainability.cofc.edu/documents/Rain\%20barrel\%20tips

City of Portland Environmental Services. (2011). How to Manage Stormwater: Rain barrels. Retrieved from https:// www.portlandoregon.gov/bes/article/378190

Dukes, M., Miller, G. L., \& Haley, M. B. (2005). Residential irrigation efficiency assessment monitoring: Final report (SJ2006-SP15). Retrieved from: ftp://secure.sjrwmd.com/ technicalreports/SP/SJ2006-SP15.pdf

Florida-Friendly Landscaping ${ }^{\mathrm{TM}}$ Program. (2009). Floridafriendly landscaping ${ }^{\mathrm{TM}}$. Retrieved from http://ffl.ifas.ufl.edu/
Forsyth County Extension Services. (2015). Forsyth Creek Week Rain Barrel Sale! North Carolina State and North Carolina A\&T Cooperative Extension [Fact Sheet]. Retrieved from http://www.rainbarrelprogram.org/fcc

Hartup, W., \& Ellis, D. (2007). Rain barrels. North Carolina State and North Carolina A\&T State University [Fact Sheet]. Retrieved from https://guilford.ces.ncsu.edu/files/ library/41/rainbarrel-2008.pdf

Kinkade-Levario, H. (2007). Examples of first flush diverters. Retrieved from http://cals.arizona.edu/cochise/ waterwise/first_flush_diverters.pdf

Kloss, C. (2008). Managing wet weather with green infrastructure municipal handbook: Rainwater harvesting policies (EPA-833-F-08-010). Retrieved from http://water. epa.gov/infrastructure/greeninfrastructure/upload/gi_munichandbook_harvesting.pdf

McKenzie-Mohr, D. (2011). Fostering sustainable behavior: Community-based social marketing. Retrieved from http:// www.cbsm.com/public/world.lasso

Mendez, C.B., Afshar, B.R., Kinney, K., Barrett, M.E., \& Kirisits, M.J. (2010). Effect of roof material on water quality for rainwater harvesting systems. Retrieved from http://greywateraction.org/wp-content/uploads/2014/11/ Effect-of-Roof-Material-on-Water-Quality-for-RainwaterHarvesting-Systems.pdf

Minnesota Pollution Control Agency. (2015). Stormwater re-use and rainwater harvesting. Retrieved from http://stormwater.pca.state.mn.us/index.php/ Stormwater_re-use_and_rainwater_harvesting

Monaghan, P. F., Warner, L., Telg, R., \& Irani, T. (2014). Improving Extension program development using audience segmentation. WC188. Gainesville: University of Florida Institute of Food and Agricultural Sciences. Retrieved from http://edis.ifas.ufl.edu/wc188

Ott, E. S., Monaghan, P. F., Israel, G. D., Gouldthorpe, J. L., \& Wilber, W. (2015). Rain barrel owners as a piece of the water conservation puzzle: Segmenting Extension audiences using their landscape water conservation practices. Journal of Extension. 53(2). Retrieved from http://www.joe. org/joe/2015april/pdf/JOE_v53_2rb5.pdf

Rogers, E. M. (2003). Diffusion of innovations. 5th ed. New York, NY: Free Press. 
Rutgers University Water Resources Program. (2014). Projects and programs: Rain gardens and rain barrels. Retrieved from http://water.rutgers.edu/Stormwater_Management/ rainbarrels.html

Southwest Florida Water Management District. (n.d.). Recycle the rain: A how-to for installing a rain barrel. Retrieved from https://www.swfwmd.state.fl.us/conservation/ rainbarrel/

Stern, P. C. (2000). Toward a coherent theory of environmentally significant behavior. Journal of Social Issues, 56(3), 407-424. Retrieved from: http://search.ebscohost.com/ login. aspx ?direct $=$ true $\&$ AuthType $=\mathrm{ip}$, uid $\& \mathrm{db}=\mathrm{aph} \& \mathrm{AN}=3$ 997994\&site=ehost-live

Stormwater Coalition of Albany County. (2010). Guidance manual for homeowners: Managing stormwater runoff using green infrastructure. Retrieved from http://www. stormwateralbanycounty.org/wp-content/uploads/2011/12/ GuidanceManual_Homeowners_DwnspoutDisc_RainGarden_RainBarrels1.pdf

Tennessee Yards \& Neighborhoods. (n.d.). Rain barrels make good sense. https://extension.tennessee.edu/publications/Documents/W276.pdf

Texas Water Development Board. (2005). The Texas manual on rainwater harvesting. Austin, Texas. Retrieved from http://www.twdb.texas.gov/publications/brochures/conservation/doc/RainwaterHarvestingManual_3rdedition.pdf

UF/IFAS Extension. (2008). Solutions: Sustainable living. Retrieved from http://solutionsforyourlife.ufl.edu/ sustainable_living/

Warner, L., Martin, E., Lamm, A., Rumble, J., \& Cantrell, R. (2015). Encouraging landscape water-conservation behaviors \#1: Tailoring programs to Florida residents who use irrigation in the home landscape. WC199. Gainesville: University of Florida Institute of Food and Agricultural Sciences. http:// edis.ifas.ufl.edu/wc199.

Warner, L. \& Monaghan, P. F. (2013). Using audience commitment to increase behavior changes in sustainable landscaping. WC154. Gainesville: University of Florida Institute of Food and Agricultural Sciences. http://edis.ifas. ufl.edu/wc154. 